СУХОНОС

Юрій Сергійович
УДК $339.727 .22+327.81$ МОЖЛИВОСТІ ТА ЗАГРОЗИ ВІД ПРЯМИХ ІНОЗЕМНИХ ІНВЕСТИЦІЙ
КИТАЮ В ЕКОНОМКУ УКРАЇНИ

студент, КНУ ім. Т.Г. Шевченко, Інститут міжнародних відносин

\section{OPPORTUNITIES AND THREATS FROM CHINA'S FOREIGN DIRECT INVESTMENT IN THE ECONOMY OF UKRAINE}

\begin{abstract}
SUKHONOS Yurii Serhiiovych - student, Institute of International Relations of Kyiv National University after Taras Shevchenko
Досліджено роль іноземних інвестицій для економіки країни. Аналізуючи тенденції залучення міжнародних інвестицій встановлено, що йдеться про значні вкладання коштів, відповідно ие може суттєво сприяти розвитку економіки. Доведено, щуо це актуально для країн, щчо спеціалізуються на виробництві сировинної продукції та потребують фінансових ресурсів у модернізацію виробництва та залучення інноваційних технологій. Можливості та загрози від прямих іноземних інвестицій розглянуто на прикладі України та Китаю. Проаналізовано прямі інвестиції (акціонерний капітал) в економіці України за регіонами. Проаналізовано прямі інвестииії з країн світу в економічі Украйни у січні-вересні 2019 р. Обгрунтовано, щчо рівень інвестиційної привабливості залежить від середнього рівня тарифного захисту ринків. Виокремлено очікувані можливості та загрози від прямих іноземних інвестицій Китаю в економіку Украӥни. Обтрунтовано, щьо можливим позитивним наслідком залучення інвестицій з Китаю може стати нарощення промислового виробництва та збільшення кількості підприємств з переробки сільськогосподарської продукиії.
\end{abstract}

$$
* * *
$$

Исследована роль иностранных инвестиций для экономики страны. Анализируя тенденции привлечения международных инвестиций установлено, что речь идет о значительных вложения средств, соответственно это может существенно способствовать развитию экономики. Доказано, что это актуально для стран, специиализирующиися на производстве сырьевой продукции которые требуют финансовых ресурсов в модернизацию производства и привлечение инновационных технологий. Возможности и угрозы прямых иностранных инвестиций рассмотрен на примере Украины и Китая. Проанализированы прямые инвестиции (акционерный капитал) в экономике Украины по регионам. Проанализированы прямые инвестиции из стран мира в экономике Украины в январе-сентябре 2019 г. Обосновано, что уровень инвестиционной привлекательности зависит от среднего уровня тарифной защиты рынков. Выделены ожидаемые возможности и угрозы прямых иностранных инвестиций Китая в экономику Украины. Обосновано, что возможным положительным следствием привлечения инвестиций из Китая может стать наращивание промышленного производства и увеличение количества предприятий по переработке сельскохозяйственной продукции.

$$
* * *
$$

Introduction. Attracting investment is a necessary prerequisite for economic development. An investment is an asset or tangible asset that is acquired for the purpose of generating income or increasing value. In an economic sense, investment is the acquisition of goods that are not consumed today but used in the future to create wealth. In finance, an investment is a monetary asset acquired with the idea that it will make a profit in the future or later be sold at a higher price for profit.

The purpose of the paper is to explore the opportunities and threats from China's foreign direct investment in Ukraine's economy.

Results. The role of foreign investment in the country's economy is investigated. Analyzing the tendencies of attracting international investments, it was found that these are significant investments, which can significantly contribute to the development of the economy. It is proved that this is relevant for the countries that specialize in the production of raw materials and require financial resources to modernize production and attract innovative technologies. Opportunities and threats from foreign direct investment are considered on the example of Ukraine and China. Direct investments (equity) in the Ukrainian economy by regions are analyzed. The direct investments from the countries of the world in the economy of Ukraine in January-September 2019 are analyzed. It is substantiated that the level of investment attractiveness depends on the average level of tariff protection of the markets. Expected opportunities and threats from China's foreign direct investment in Ukraine's economy are highlighted. It is argued that a possible positive consequence of attracting investment from China could be an increase in industrial production and an increase in the number of agricultural processing enterprises.

Conclusion. Analyzing China's investment policy, it should be noted that there is a small amount of investment in Ukraine. At the same time, there is considerable potential for its growth. In order to stimulate China's foreign direct investment in the Ukrainian economy, a transparent and objective system of protection of creditors' and property rights, an effective system of relations between creditors and local authorities is needed. An expected positive consequence of attracting investment from China could be an increase in industrial production and an increase in the number of agricultural processing enterprises.

Ключові слова: інвестиції, Китай, міжнародні економічні відносини, кон'юнктура ринку, ефективність, зовнішньоекономічна діяльність

Ключевые слова: инвестиции, Китай, международные экономические отномения, конъюнктура рынка, эффективность, внешнеэкономическая деятельность

Keywords: investments, China, international economic relations, market conditions, efficiency, foreign economic activity 


\section{ПОСТАНОВКА ПРОБЛЕМИ}

Економіка зростає завдяки збільшенню виробництва товарів та послуг. Економічне зростання може бути результатом зростанням споживчих витрат, міжнародної торгівлі та інвестицій у бізнес. Періоди зростання спостерігаються частково через всю історію завдяки новим відкриттям як у випадку з сланцевою нафтою в 2000-х рр., що зробила США одним із провідних виробників нафти у світі [5]. Поява Інтернету принесла нові технології, електронну комерцію та зробила революцію на ринку цінних паперів. Однак інновації та технологічний прогрес не могли відбутися без капітальних вкладень, які складаються із закупівель та інвестицій компаній та інвесторів для реалізації масштабних проектів у різних сферах економіки [9].

Необхідною передумовою розвитку економіки $є$ залучення інвестицій. Інвестиція - це актив або матеріальний ресурс, придбаний з метою отримання доходу або підвищення вартості. В економічному сенсі інвестиція - це придбання товарів, які не споживаються сьогодні, але використовуються у майбутньому для створення багатства. У фінансах інвестиція - це грошовий актив, придбаний з ідеєю, що він надаватиме прибуток у майбутньому або згодом буде продаватися за вищою ціною для отримання прибутку [12].

В умовах глобалізації економіки характерним явищем стало залучення іноземних інвестицій в економіку інших країн. Водночас дане явище характеризується певними позитивними наслідками, однак може мати і певні ризики.

\section{Аналіз останніх досліджень і публікацій}

Значна кількість науковців досліджували специфіку залучення іноземних інвестицій та їх вплив на розвиток економіки каїни. Наразі сформований значний інформаційний ресурс з статистичною інформацією про стан залучення іноземних інвестицій, їх динаміку та чинники, які на це впливають. При підготовці даної публікації були використані такі інформаційні Інтернет-ресурси: Актуальні засади формування стратегічного партнерства України і КНР [1]; Геополітична ситуація Китаю. КНР [2]; Держстат України. Офіційний сайт [3]; Європа: Статистичний портал [4]; Китай, випередивши США, став першою економікою у світі [6]; ТОП-10 товарів, які світ купує в Україні. Укрінформ [14]; Trade Policy Review of China. International Centre for Trade and sustainable development [19]; Міжнародна торгова організація [9]; МВФ включив китайський юань до кошика резервних валют [7]; Основні показники зовнішньої торгівлі України. Український клуб аграрного бізнесу [11]. Також значна кількість дослідників вивчали дані питання. Так, О.Л. Попова досліджувала сталий розвиток агросфери України: можливості розширення експорту [12]. Д. Жуджунь досліджував можливості та загрози від прямих іноземних інвестицій Китаю в економіку України [5]. $\mathrm{X}$. Менг досліджував Українсько-китайські відносини наприкінці XX - початку XXI ст. [8]. Дж. фон Ней- ман, О. Моргенштерн досліджували теорію ігор та міжнародну торгівлю [10]. Ю.М. Туніцька досліджувала інструментарій забезпечення конкурентоспроможності експорту продукції харчової промисловості України. О.Д. Харт вивчав неповні контракти і теорія фірми. В.Є. Данкевич досліджував специфіку міжнародної торгівлі та залучення інвестицій.

МЕТА статті - дослідити можливості та загрози від прямих іноземних інвестицій Китаю в економіку України.

\section{РЕЗУЛЬТАТИ}

Інвестиція стосується збільшення капітальних активів і, як правило, включає інвестиції бізнесу, інвестиції у власність та інвестиції урядів у певні інфраструктурні об'єкти. Інвестиції в бізнес складають від $65 \%$ до 85 \% від загальних інвестицій у більшості країн G7 [9]. У сучасних умовах господарювання фірми інвестують 3 двох основних причин: По-перше, можуть знадобитися інвестиції для заміни зношених або несправних машин, обладнання чи будівель. Це називається споживанням капіталу і виникає внаслідок постійної амортизації основних фондів. По-друге, інвестиції можуть бути здійснені для придбання нової техніки, обладнання чи будівель 3 метою збільшення виробничих можливостей. Це зменшить довгострокові витрати, підвищить конкурентоспроможність та підвищить прибуток.

Досліджуючи міжнародні інвестиції слід відмітити, що йдеться про значні вкладання коштів, відповідно це може суттєво сприяти розвитку економіки. Особливо це стосується країн, що спеціалізуються на виробництві сировинної продукції та потребують фінансових ресурсів у модернізацію виробництва та залучення інноваційних технологій.

Можливості та загрози від прямих іноземних інвестицій розглянемо на прикладі України та Китаю. Слід відмітити, що лише частина виробленої продукції вітчизняними товаровиробниками є товарно. Товарна структура експорту сільськогосподарської та продовольчої продукції представлена у табл. 1. Водночас, для того щоб розширити товарну структуру, необхідні відповідні інвестиції. Наразі Україна виробляє та експортує переважно сировину, яку переробляють країниімпортери.

Залучення інвестицій, в т.ч. 3 Китаю та направлення їх на модернізацію виробничих потужносте вітчизняних підприємств сприятиме налагодженню виробництва продукції з доданою вартістю, пришвидшить темпи економічного зростання.

Водночас сьогодні на темпи економічного зростання також впливає рівень та динаміка інвестицій. Інвестиції у бізнес, як правило, досить мінливі. Якщо бізнес побачить покращення економічних прогнозів, то збільшить інвестиції для задоволення майбутнього попиту. Тому покращення темпів економічного зростання може спричинити значне зростання інвестицій. Але якщо буде економічний спад, бізнес скоротить інвестиції. 
Таблиця 1

Товарна структура експорту сільськогосподарської та продовольчої продукції України (тис. дол. США)

\begin{tabular}{|c|c|c|c|c|c|c|}
\hline $\begin{array}{c}\text { Код і назва товарів } \\
\text { згідно з УКТЗЕД }\end{array}$ & 2010 & 2014 & 2015 & 2016 & 2017 & 2018 \\
\hline Усього (коди 1-24) & 9935978,5 & 17038805,3 & 16668953,8 & 14563144,5 & 15281802,6 & 17756854,1 \\
\hline $\begin{array}{c}\text { I. Живі тварини; продукти } \\
\text { тваринного походження }\end{array}$ & 771386,6 & 1084105,1 & 1014473,9 & 823434,9 & 775036,9 & 1108757,0 \\
\hline $\begin{array}{c}\text { II. Продукти рослинного } \\
\text { походження }\end{array}$ & 3976213,4 & 8875920,1 & 8736139,2 & 7971492,5 & 8093693,7 & 9215707,9 \\
\hline $\begin{array}{c}\text { III. 15 Жири та олії тваринного } \\
\text { або рослинного походження }\end{array}$ & 2617314,4 & 3507076,4 & 3822031,8 & 3299799,1 & 3962975,8 & 4605666,2 \\
\hline IV. Готові харчові продукти & 2571064,1 & 3571703,7 & 3096308,9 & 2468418,0 & 2450096,2 & 2826723,0 \\
\hline
\end{tabular}

*Дані наведено без урахування тимчасово окупованої території Автономної Республіки Крим, м. Севастополя та частини тимчасово окупованих територій у Донеиькій та Луганській областях.

Таблиця 2

Прямі інвестиції (акціонерний капітал) в економіці України по регіонах у січні-вересні 2019 р.

\begin{tabular}{|c|c|c|c|c|}
\hline & \multicolumn{4}{|c|}{ Обсяги станом на } \\
\hline & \multicolumn{2}{|c|}{01.01 .2019} & \multicolumn{2}{|c|}{01.10 .2019} \\
\hline & млн. дол. США & $\begin{array}{c}\text { у \% до } \\
\text { підсумку }\end{array}$ & млн. дол. США & $\begin{array}{c}\text { у \% до } \\
\text { підсумку }\end{array}$ \\
\hline Усього & 32911,0 & 100,0 & 34727,6 & 100,0 \\
\hline Вінницька & 222,8 & 0,7 & 237,5 & 0,7 \\
\hline Волинська & 265,9 & 0,8 & 288,7 & 0,8 \\
\hline Дніпропетровська & 3535,7 & 10,7 & 3765,2 & 10,8 \\
\hline Донецька & 1289,5 & 3,9 & 1398,5 & 4,0 \\
\hline Житомирська & 234,2 & 0,7 & 243,6 & 0,7 \\
\hline Закарпатська & 343,3 & 1,0 & 348,6 & 1,0 \\
\hline Запорізька & 900,8 & 2,7 & 925,0 & 2,7 \\
\hline Івано-Франківська & 894,6 & 2,7 & 858,7 & 2,5 \\
\hline Київська & 1596,9 & 4,9 & 1638,7 & 4,7 \\
\hline Кіровоградська & 69,3 & 0,2 & 75,0 & 0,2 \\
\hline Луганська & 437,2 & 1,3 & 449,1 & 1,3 \\
\hline Львівська & 947,8 & 2,9 & 1005,9 & 2,9 \\
\hline Миколаївська & 220,7 & 0,7 & 253,3 & 0,7 \\
\hline Одеська & 1251,3 & 3,8 & 1271,1 & 3,7 \\
\hline Полтавська & 1024,7 & 3,1 & 1159,9 & 3,3 \\
\hline Рівненська & 130,4 & 0,4 & 134,8 & 0,4 \\
\hline Сумська & 184,5 & 0,6 & 199,9 & 0,6 \\
\hline Тернопільська & 100,6 & 0,3 & 49,3 & 0,1 \\
\hline Харківська & 652,5 & 2,0 & 755,0 & 2,2 \\
\hline Херсонська & 204,8 & 0,6 & 246,9 & 0,7 \\
\hline Хмельницька & 200,5 & 0,6 & 196,4 & 0,6 \\
\hline Черкаська & 329,8 & 1,0 & 358,9 & 1,0 \\
\hline Чернівецька & 45,6 & 0,1 & 52,8 & 0,2 \\
\hline Чернігівська & 435,7 & 1,3 & 440,3 & 1,3 \\
\hline м. Київ & 17392,0 & 52,8 & 18374,6 & 52,9 \\
\hline
\end{tabular}

*Дані наведено без урахування тимчасово окупованої території Автономної Республіки Крим, м. Севастополя та частини тимчасово окупованих територій у Донецькій та Луганській областях. 
Для збалансованого розвитку економіки важливим також $\epsilon$ рівномірний розподіл інвестицій за регіонами. Наразі прямі іноземні інвестиції в Україні спрямовуються у м. Київ, де зареєстрована значна кількість підприємств. Це має певні негативні наслідки для регіонального розвитку та наповнення регіональних бюджетів. Прямі інвестиції (акціонерний капітал) в економіці України по регіонах у січні-вересні 2019 р. представлено у табл. 2.

Враховуючи сучасні глобальні виклики значна кількість країн сьогодні вкладають кошти закордон. Україна цікава для інвестування у зв'язку із наявністю значної кількості цінних ресурсів, вигідним географічним розташуванням та виходом до міжнародних логістичних систем.

Інвестування на рівні країн - це вкладення коштів, щоб розпочати або розширити проект, з метою отримання прибутку та збільшення вартості з часом. Термін інвестиція може означати будь-який механізм, що використовується для отримання майбутніх доходів. У фінансовому сенсі це включає придбання облігацій, акцій або нерухомості серед кількох інших. Крім того, споруджена будівля чи інший об'єкт, що використовується для виробництва товарів, може розглядатися як інвестиція. Виробництво товарів, необхідних для виробництва інших товарів, також може розглядатися як інвестиції.

Вжиття заходів із збалансування виробництва, його модернізації, у надії на підвищення майбутніх доходів також може вважатися інвестицією. Наприклад, вибираючи здобути додаткову освіту, мета часто полягає у збільшенні знань та вдосконаленні навичок, сподіваючись у кінцевому підсумку отримати більший дохід [10].

Оскільки інвестування орієнтоване на майбутнє зростання чи дохід, існує ризик, пов'язаний з інвестицією у випадку, якщо це не забезпечить очікуваного прибутку. Наприклад, вкладення коштів у компанію, що закінчується банкрутством, або проект, який провалюється. Це те, що відокремлює вкладення коштів від заощадження. Заощадження - це накопичення грошей для подальшого використання, яке не загрожує ризиком, тоді як інвестиції покладають гроші на роботу для майбутнього прибутку і тягнуть за собою певний ризик. Ризик зростає, коли кошти вкладаються іншою країною.

Прямі інвестиції (акціонерний капітал) 3 країн світу в економіці України у січні-вересні 2019 р. представлено у табл. 3 .

Прямі інвестиції (акціонерний капітал) з країн світу в економіці України у січні-вересні 2019 р. [розраховано за даними [6,11,19]]

\begin{tabular}{|l|c|c|c|c|}
\hline \multirow{2}{*}{} & \multicolumn{3}{|c|}{ Обсяги станом на } \\
\cline { 2 - 5 } & \multicolumn{2}{|c|}{01.01 .2019} & \multicolumn{2}{c|}{01.10 .2019} \\
\cline { 2 - 5 } & млн. дол. США & $\begin{array}{c}\text { у \% до } \\
\text { підсумку }\end{array}$ & млн. дол. США & у \% до підсумку \\
\hline Усього & 32911,0 & 100,0 & 34727,6 & 100,0 \\
\hline Свропа & 18788,4 & 56,8 & 19632,0 & 56,4 \\
\hline Азія & 11034,2 & 33,5 & 11873,5 & 34,2 \\
\hline Китай & 34,0 & 0,1 & 38,8 & 0,1 \\
\hline Африка & 124,6 & 0,3 & 135,3 & 0,3 \\
\hline Америка & 2902,2 & 8,7 & 3022,5 & 8,7 \\
\hline Австралія і Океанія & 48,9 & 0,1 & 51,2 & 0,1 \\
\hline
\end{tabular}

Наразі найбільшим інвестором для України є Свропейський регіон. Так, країни Свропи станом на 01.01.2019 р. інвестували 18 788,4 млн. дол. США, Азії - 11 034,2, Африки - 124,6, Америки - 2 902,2, Австралії і Океанії - 48,9. Досліджуючи специфіку інвестицій з Китаю в Україну слід відмітити, що до 2020 р. країна може стати найбільшим транскордонним інвестором [17].

Основними напрямами інвестицій наразі є аграрний та будівельний. Водночас основними перепонами залучення інвестицій $є$ інфляційні ризики, політична нестабільність у країні та рівень корупції. Інвестиції обернено пов'язані з процентними ставками, які є витратами на запозичення та винагородою за позику. Інвестиції обернено пов'язані з процентними ставками 3 двох основних причин. По-перше, якщо процентні ставки зростають, можлива вартість інвестицій зростає. Це означає, що підвищення процентних ставок збільшує рентабельність коштів, закладених на процентному рахунку, або від надання позики, що зменшує привабливість інвестицій 3 кредитування. По- друге, якщо відсоткові ставки зростають, фірми можуть передбачити, що споживачі зменшать свої витрати, а вигода від інвестування буде втрачена. Рівень інвестиційної привабливості також залежить від середнього рівня тарифного захисту ринків. Так, середній рівень тарифного захисту ринків України і Китаю (за загальним тарифом) представлено на рис. 1 .

Середній рівень тарифного захисту ринків України і Китаю (по сільськогосподарських товарах) представлено на рис. 2.

Середній рівень тарифного захисту ринків України і Китаю (по несільськогосподарських товарах) представлено на рис. 3.

Оцінка інвестицій, в т.ч. із Китаю, залежить від типу інвестицій. Наприклад, неправильні державні інвестиції у покращення виробничих потужностей можуть бути неефективними та не сприятимуть підвищенню продуктивності в економіці. Інвестиції приватного сектору або інвестиції з-за кордону можуть бути набагато ефективнішими для фактичного підвищення продуктивності. 


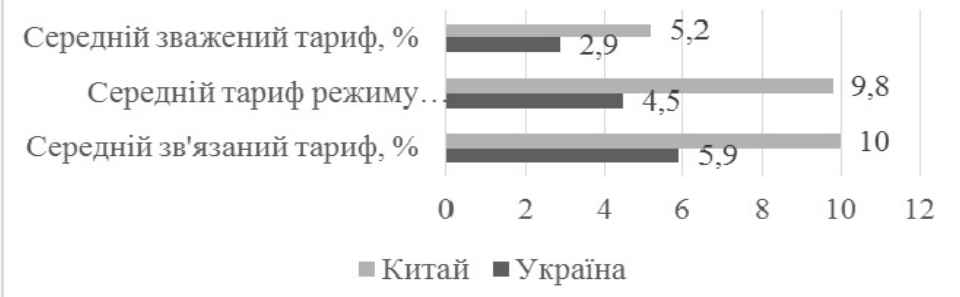

Рис. 1. Середній рівень тарифного захисту ринків Украӥни і Китаю (за загальним тарифом), 2018 р. [розраховано за даними $[6,11,17]]$

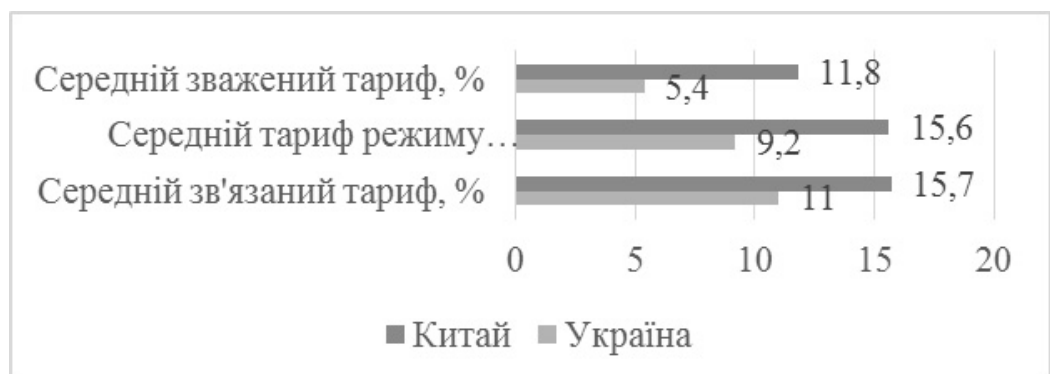

Рис. 2. Середній рівень тарифного захисту ринків Украӥни і Китаю (за сільськогосподарськими товарами), 2018 р. [розраховано за даними $[6,11,17]]$

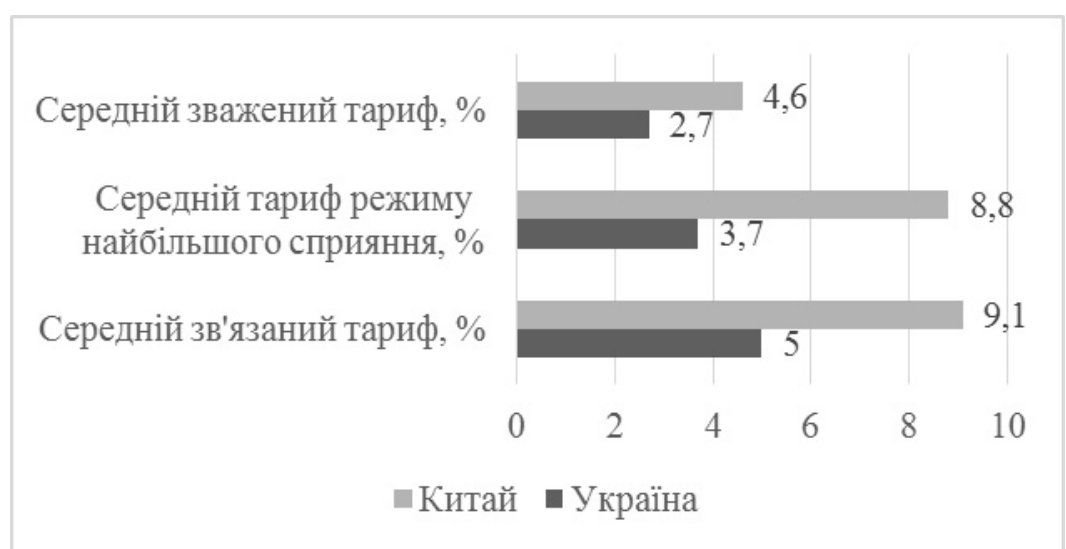

Рис. 3. Середній рівень тарифного захисту ринків України і Китаю (за несільськогосподарськими товарами), 2018 р. [розраховано за даними [6,11,17]]

Очікувані можливості від прямих іноземних інвестицій Китаю в економіку України: 1. За належного державного контролю дані інвестиції сприятимуть нарощенню виробництва продукції. 2. Інвестиції можуть залучатися також на модернізацію виробництва із використання китайських технологій. 3. Перспективним напрямом для України є залучення інвестицій 3 метою створення спільних підприємств на території України на потужностях промислових об'єктів.

Можливі загрози від прямих іноземних інвестицій Китаю в економіку України 1. Варто зазначити, що Китай виділяє кредитування, як правило, під закупівлю обладнання, виробленого в Китаї. 2. Компанії 3 Китаю часто недотримуються виробничих та екологічних вимог, чим завдають шкоду екології. 3. Китайська модель інвестицій не спрямована на створення додаткових робочих місць для місцевого населення, розвитку національного виробництва, виробництва продуктів 3 доданою вартістю. 4. Ключовою метою китайських інвестицій $є$ максимальне використання наявних ресурсів, країни куди інвестуються кошти. У перспективі інвестиції, в т.ч. із Китаю, мають важливе значення для підвищення продуктивності праці та підвищення конкурентоспроможності економіки.
Без інвестицій економіка могла б користуватися високим рівнем споживання, але це створює незбалансовану економіку.

\section{ВИСНОВКИ}

Якщо інвестиції ефективні, то це також повинно збільшити виробничий потенціал економіки. Наприклад, інвестиції в навички та освіту можуть підвищити продуктивність праці. Інвестиції у нові технології та капітал можуть підвищити продуктивність праці та виробничий потенціал економіки. Збільшення іноземних інвестицій має важливе значення для довгострокового економічного зростання; це може збільшити економічне зростання без інфляції. Якщо інвестиції призводять до значного зростання продуктивності, то це може призвести до зростання темпів економічного зростання у довгостроковій перспективі. Аналізуючи інвестиційну політику Китаю слід відмітити про незначний обсяг інвестицій в Україну. Водночас значний потенціал для його нарощування. 3 метою активізації прямих іноземних інвестицій Китаю в економіку України необхідна прозора і об'єктивна система захисту прав кредиторів і права власності, ефективна система взаємовідносин кредиторів та місцевої влади. 
Очікуваним позитивним наслідком залучення інвестицій з Китаю може стати нарощення промислового виробництва та збільшення кількості підприємств 3 переробки сільськогосподарської продукції.

\section{Список використаних джерел}

1. Актуальні засади формування стратегічного партнерства України і KHP. URL: http://old.niss.gov.ua/ Table/01092010/0901 dopov.pdf

2. Геополітична ситуачія Китаю. KHP. URL: http://www.geograf.com.ua/geoinfocentre/23-countries-stydingtourism/289-geopolitychna-sytuatsiya-kytau

3. Держстат Украӥни. Офіиійний сайт. URL: http://www.ukrstat.gov.ua.

4. Свропа: Статистичний портал. URL: https://de.statista.com/statistik/daten/studie/37013/umfrage/ran king-der-top-20-exportlaender-weltweit/

5. Жуджунь Д. Феномен экономического развития Китая. Мн.: Издат. иентр БГУ, 2008. 446 с.

6. Китай, випередивши США, став першою економікою в cвimi. URL: http://www.ukrinform.ua/ukr/news/

7. МВФ включив китайський юань до кочика резервних валют. URL : http://economics.unian.ua/finance/1198555-mvfvklyuchiv-kitayskiyyuan-do-koshika-rezervnih-valyut.html.

8. Менг Х. Украйнсько-китайські відносини наприкінці ХХ - початку ХХІ століття: автореф. дис. ... канд. істор. наук: 07.00.02 / Київський славістичний університет. К., 2005. $20 \mathrm{c}$.

9. Міжнародна торгова організаиія. електронний pecypc. URL: https://www.trade.gov/topmarkets/environmentaltech.asp.

10. Нейман Дж. фон, Моргенштерн О. Теория игр и экономическое поведение / пер. с англ.; под ред. Н.Н. Воробьева. Москва: Наука, 1970. 708 с.

11. Основні показники зовнішньої торгівлі України. Украӥнський клуб аграрного бізнесу. URL: http://ucab.ua/ual doing_agribusiness/zovnishni_rinki/osnovni_pokazniki_zovnish noi_torgivli_ukraini

12. Попова О.Л. Сталий розвиток агросфери Украӥни: політика $і$ механізми / НАН Украйни, Ін-т екон. та прогнозув. К., 2009. С. 179-183.

13. Руст А.М. Бизнес-модель инновационного развития предприятия. Вестник Саратовского государственного технического университета. 2010. № 4 (49). С. 252-257. URL: http://lib.sstu.ru.

14. ТОП-10 товарів, які світ купуе в Украӥні. Укрінформ. URL: https://www.ukrinform.ua/rubriceconomy/2555181-top10-tovariv-aki-svit-kupue-v-ukraini.html.

15. Alchian A., Demsetz H. Production, Information Costs and Economic Organization. American Economic Review. 1972. Vol. 62. pp. 775-795.

16. Dankevych V., Dankevych Y., Pyvovar P. Clustering of the international agricultural trade between Ukraine and the EU. Management Theory and Studies for Rural Business and Infrastructure Development. 2018. Vol. 40. № 3. pp. 307-319.

17. Trade Policy Review of China. International Centre for Trade and sustainable development. URL: http://www.ictsd.org/bridges-news

\section{$\underline{\text { References }}$}

1. Current Principles of Strategic Partnership between Ukraine and China. URL: http://old.niss.gov.ua/Table/ 01092010/0901_dopov.pdf (in Ukrainian)

2. China's Geopolitical Situation. PRC. URL: http://www.geograf.com.ua/geoinfocentre/23-countries-stydingtourism/289-geopolitychna-sytuatsiya-kytau (in Ukrainian)

3. State Statistics Committee of Ukraine. Official website. URL: http://www.ukrstat.gov.ua. (in Ukrainian)

4. Europe: Statistical Portal (2019). Available from: https://de.statista.com/statistik/

daten/studie/37013/umfrage/ranking-der-top-20-exportlaenderweltweit/.(in German)

5. Zhudzhun D. The Phenomenon of China's Economic Development. BSU Publishing Center, Minsk, 2008. 446 p. (in Russian).

6. China, having Outpaced the United States, Became the First Economy in the World. URL: http://www.ukrinform.ua/ eng/news/ (in Ukrainian)

7. The IMF has Included the Chinese Yuan in the Reserve Currency Basket. URL: http://economics.unian.ua/finance /1198555-mvf-vklyuchiv-kitayskiyyuan-do-koshika-rezervnihvalyut.html. (in Ukrainian)

8. Meng Kh. Ukrainian-Chinese Relations in the Late $20^{\text {th }}$ Early $21^{\text {st }}$ Centuries: author's abstract of diss ... cand. hist. sciences: 07.00.02 /Kyiv Slavic University. Kyiv, 2005. 20 p. (in Ukrainian)

9. International Trade Organization. URL: https://www.trade.gov/topmarkets/environmental-tech.asp. (in Ukrainian)

10. Neyman Dzh. von, Morgenshtern O. The Theory of Games and Economic Behaviour / transl. from English; ed. N.N. Vorobyev. Moscow: Nauka, 1970. 708 p. (in Russian).

11. The Main Indicators of Foreign trade of Ukraine. Ukrainian Agrarian Business Club. URL: http://ucab.ua/en/ doing_agribusiness/zovnishni_rinkil

basic_indicators_zovnishnoi_torgivli_ukraini. (in Ukrainian)

12. Popova O.L. Sustainable Development of Ukraine's Agrosphere: Policy and Mechanisms / NAS of Ukraine, Institute for Economics and Forecasting. Kyiv, 2009. pp. 179-183. (in Ukrainian)

13. Rust A.M. (2010). Business Model of Innovative Development of the Enterprise. Bulletin of the Saratov State Technical University. 2010. № 4 (49). pp. 252-257. URL: http://lib.sstu.ru. (in Russian).

14. TOP-10 Goods that the World Buys in Ukraine. Ukrinform. URL: https://www.ukrinform.ua/rubriceconomy/2555181-top10-tovariv-aki-svit-kupue-v-ukraini.html. (in Ukrainian)

15. Alchian A., Demsetz H. Production, Information Costs and Economic Organization. American Economic Review. 1972. Vol. 62. pp. 775-795.

16. Dankevych V., Dankevych Y., Pyvovar P. Clustering of the international agricultural trade between Ukraine and the EU. Management Theory and Studies for Rural Business and Infrastructure Development. 2018. Vol. 40. № 3. pp. 307-319.

17. Trade Policy Review of China. International Centre for Trade and sustainable development. URL: http://www.ictsd.org/bridges-news 